\title{
Antitubercular therapy-induced psychosis
}

Bhanudeep Singanamala, MD, Lokesh Saini, DM, Priyanka Madaan, DM, Paramjeet Singh, MD,

Pankaj C. Vaidya, MD, and Jitendra Kumar Sahu, DM

Neurology ${ }^{\circledR}$ 2019;93:1012-1013. doi:10.1212/WNL.0000000000008578

Figure 1 Brain MRI of the index patient at the time of presentation

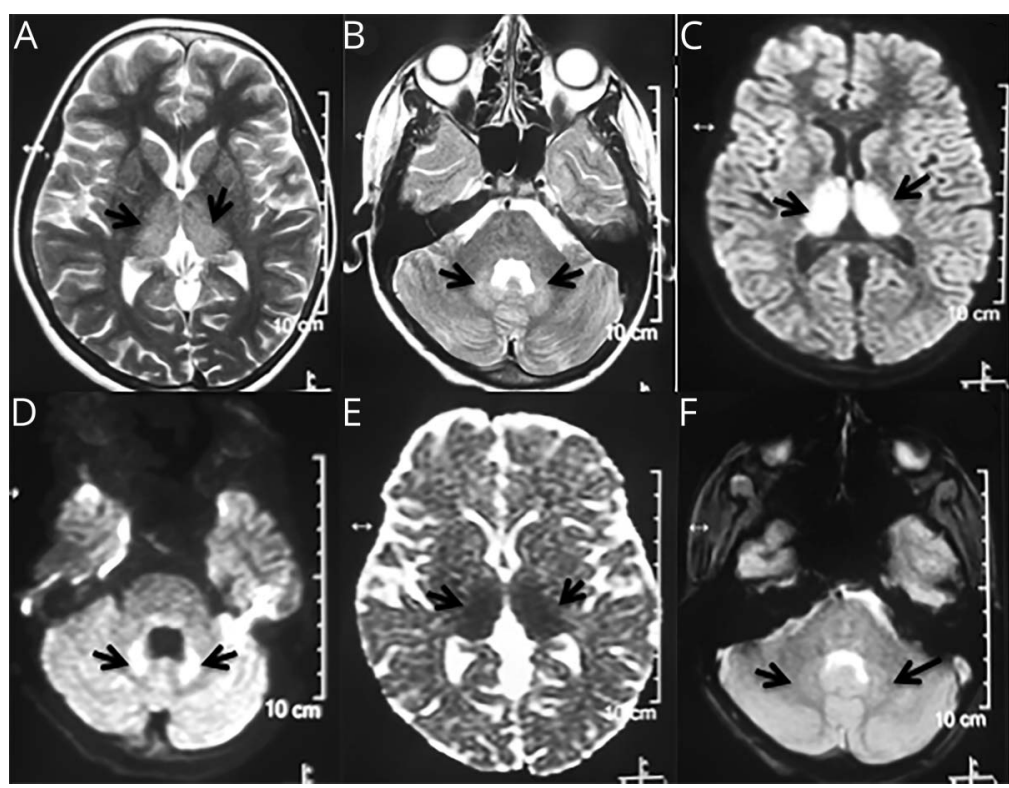

Brain MRI (T2-weighted [A, B], diffusion-weighted [C, D], and apparent diffusion coefficient images $[E, F]$ ) reveals T2-hyperintense thalami and dentate nuclei along with diffusion restriction in bilateral thalami and vasogenic edema in the dentate nuclei (C, F). These radiologic findings are consistent with cycloserine toxicity in the described clinical setting.

A 12-year-old girl with multidrug-resistant pulmonary tuberculosis presented with a 5-day history of headache and psychosis; at the time, she was taking a complex antitubercular therapy (ATT; kanamycin, levofloxacin, ethionamide, pyrazinamide, cycloserine, ethambutol) and pyridoxine. Examination revealed fluctuating sensorium and aggression. The differentials included neurotuberculosis, immune-reconstitution-inflammatory syndrome, and drug-induced psychosis. Neuroimaging revealed features of cycloserine-induced encephalopathy (CIE; figure 1, A-F). Cycloserine was replaced with linezolid and there was a complete resolution of the clinicoradiologic presentation over 4 weeks (figure 2, A-D), confirming the diagnosis.

Cycloserine, an NMDA partial agonist, is widely used in ATT regimens. It can cause reversible encephalopathy. ${ }^{1}$ Clinicians should be aware of CIE when considering treatment options.

\section{Correspondence}

Dr. Saini

drlokeshsaini@gmail.com

\section{Acknowledgment}

The authors thank the parents of the patient for the images.

\section{Study funding}

No targeted funding reported.

From the Pediatric Neurology Unit, Department of Pediatrics, Advanced Pediatrics Centre (B.S., L.S., P.M., P.C.V., J.K.S.), and Department of Radiodiagnosis (P.S.), Post Graduate Institute of Medical Education \& Research, Chandigarh; and Council of Scientific and Industrial Research (P.M.), New Delhi, India.

Go to Neurology.org/N for full disclosures. Funding information and disclosures deemed relevant by the authors, if any, are provided at the end of the article. 


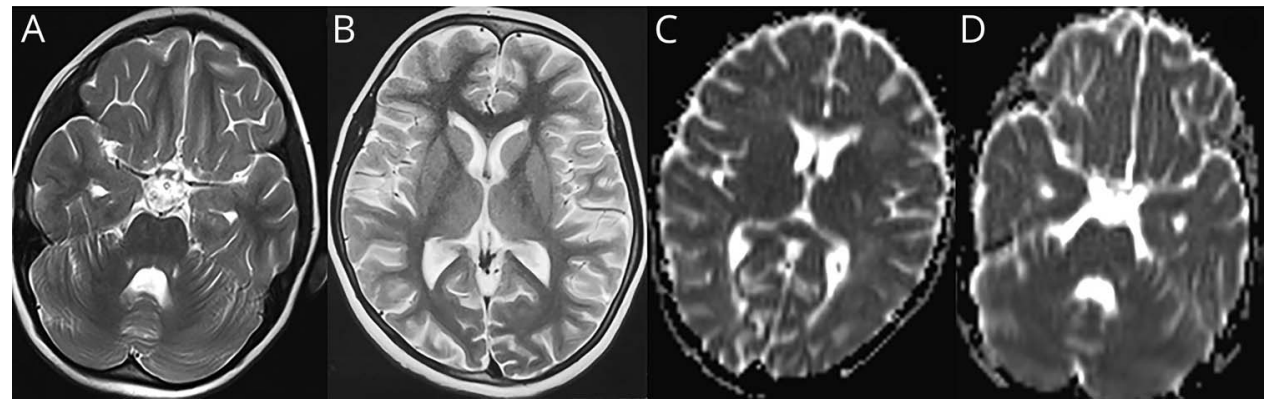

Repeat brain MRI 4 weeks later (T2-weighted [A, B] and apparent diffusion coefficient images [C, D]) reveal the complete resolution of thalamic and dentate signal changes and diffusion abnormalities.

\section{Disclosure}

The authors report no disclosures relevant to the manuscript. Go to Neurology.org/N for full disclosures.

Appendix Authors

\begin{tabular}{llll}
\hline Name & Location & Role & Contribution \\
\hline $\begin{array}{l}\text { Bhanudeep } \\
\text { MDganamala, }\end{array}$ & $\begin{array}{l}\text { PGIMER, } \\
\text { Chandigarh, } \\
\text { India }\end{array}$ & Author & $\begin{array}{l}\text { Patient management, } \\
\text { literature review, initial draft } \\
\text { manuscript preparation }\end{array}$ \\
\hline $\begin{array}{l}\text { Lokesh Saini, } \\
\text { MD, DM }\end{array}$ & $\begin{array}{l}\text { PGIMER, } \\
\text { Chandigarh, } \\
\text { India }\end{array}$ & Author & $\begin{array}{l}\text { Concept and design of the } \\
\text { study, analysis of the } \\
\text { radiologic data, critical } \\
\text { review of the manuscript, } \\
\text { final approval of the version } \\
\text { to be published }\end{array}$ \\
$\begin{array}{l}\text { Priyanka } \\
\begin{array}{l}\text { Madaan, MD, } \\
\text { DM }\end{array}\end{array}$ & $\begin{array}{l}\text { PGIMER, } \\
\text { Chandigarh, } \\
\text { India }\end{array}$ & Author & $\begin{array}{l}\text { Patient management, } \\
\text { literature review, initial draft } \\
\text { manuscript preparation }\end{array}$ \\
\hline
\end{tabular}

Appendix (continued)

\begin{tabular}{|c|c|c|c|}
\hline Name & Location & Role & Contribution \\
\hline $\begin{array}{l}\text { Paramjeet } \\
\text { Singh, MD }\end{array}$ & $\begin{array}{l}\text { PGIMER, } \\
\text { Chandigarh, } \\
\text { India }\end{array}$ & Author & $\begin{array}{l}\text { Analysis of the radiologic } \\
\text { data, critical review of } \\
\text { manuscript, final approval of } \\
\text { the version to be published }\end{array}$ \\
\hline $\begin{array}{l}\text { Pankaj C. } \\
\text { Vaidya, MD }\end{array}$ & $\begin{array}{l}\text { PGIMER, } \\
\text { Chandigarh, } \\
\text { India }\end{array}$ & Author & $\begin{array}{l}\text { Patient management, critical } \\
\text { review of manuscript, final } \\
\text { approval of the version to be } \\
\text { published }\end{array}$ \\
\hline $\begin{array}{l}\text { Jitendra } \\
\text { Kumar Sahu, } \\
\text { MD, DM }\end{array}$ & $\begin{array}{l}\text { PGIMER, } \\
\text { Chandigarh, } \\
\text { India }\end{array}$ & Author & $\begin{array}{l}\text { Patient management, critical } \\
\text { review of manuscript for } \\
\text { important intellectual } \\
\text { content, final approval of the } \\
\text { version to be published }\end{array}$ \\
\hline
\end{tabular}

\section{Reference}

1. Kim S, Kang M, Cho JH, Choi S. Reversible magnetic resonance imaging findings in cycloserine-induced encephalopathy: a case report. Neurol Asia 2014;19:417-419.

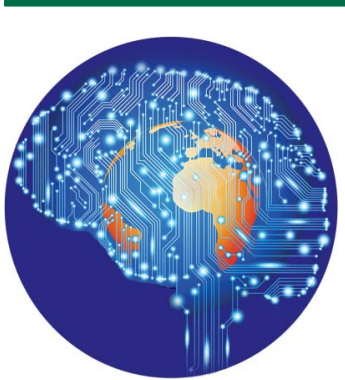

\section{Practice Current: An interactive exchange on controversial topics}

Share your own best practices.

Read commentary with expert opinion.

Explore results on an interactive world map.
NPub.org/NCP/practicecurrent
Neurology ${ }^{\circledR}$ Clinical Practice 


\title{
Neurology
}

\author{
Antitubercular therapy-induced psychosis \\ Bhanudeep Singanamala, Lokesh Saini, Priyanka Madaan, et al. \\ Neurology 2019;93;1012-1013 \\ DOI 10.1212/WNL.0000000000008578
}

This information is current as of December 2, 2019

Updated Information \& Services

References

Subspecialty Collections

Permissions \& Licensing

Reprints including high resolution figures, can be found at: http://n.neurology.org/content/93/23/1012.full

This article cites 1 articles, 0 of which you can access for free at: http://n.neurology.org/content/93/23/1012.full\#ref-list-1

This article, along with others on similar topics, appears in the following collection(s):

\section{Bacterial infections}

http://n.neurology.org/cgi/collection/bacterial_infections MRI

http://n.neurology.org/cgi/collection/mri

Information about reproducing this article in parts (figures,tables) or in its entirety can be found online at:

http://www.neurology.org/about/about_the_journal\#permissions

Information about ordering reprints can be found online:

http://n.neurology.org/subscribers/advertise

Neurology ${ }^{\circledR}$ is the official journal of the American Academy of Neurology. Published continuously since 1951, it is now a weekly with 48 issues per year. Copyright @ 2019 American Academy of Neurology. All rights reserved. Print ISSN: 0028-3878. Online ISSN: 1526-632X.

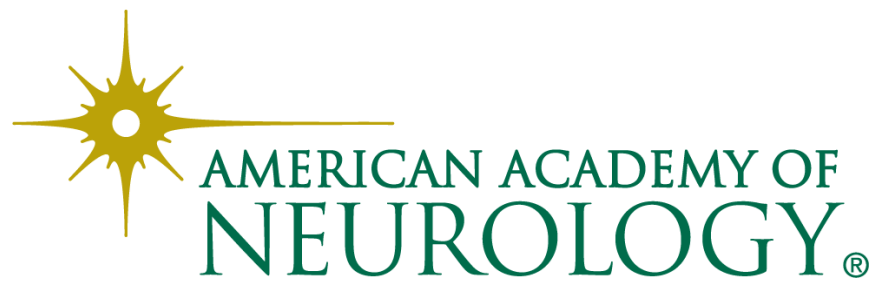

